\title{
Replacing $30 \%$ chemical fertilizer with organic fertilizer increases the fertilizer efficiency, yield and quality of cabbage in intensive open-field production
}

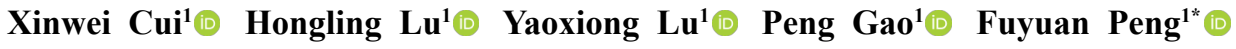

${ }^{1}$ Institute of Agro-Environment and Ecology, Hunan Academy of Agricultural Sciences, Changsha, P.R. China. E-mail: 54856859@qq.com. ${ }^{*}$ Corresponding author.

ABSTRACT: The combined application of chemical fertilizer and organic fertilizer is an effective way to improve soil fertility, crop yield and quality. In this study, a field experiment was conducted to evaluate the yield, quality and fertilizer use efficiency of cabbage (Brassica oleracea var. capitata L.) grown under different ratios of organic fertilizer replacing chemical fertilizer at a rate of $225 \mathrm{~kg} \mathrm{~N} \mathrm{hal}$ in 2019 and 2020 . The fertilizer treatments included NO (non nitrogen fertilizer), CK (only compound fertilizer was applied, N:P:K=15.0\%:6.5\%:12.4\%), T1, T2 and T3 (organic fertilizer replaced $15 \%, 30 \%$ and $45 \%$ chemical fertilizer, respectively), and T4 (total nutrient input was reduced by $10 \%$ under T2). Results showed that T2 had the highest marketable yield and fertilizer use efficiency, as well as the best quality. The marketable yield, vitamin $C$ content, soluble sugar content, $R E_{N}$ (apparent uptake efficiency of fertilizer $N$ ) and AE $E_{N}$ (agronomic $N$ use efficiency) of T2 increased by $32.2 \%, 14,9 \%, 5.5 \%, 97 . \%$ and $55.6 \%$, respectively, in contrast, the crude fibers decreased by $34.0 \%$, compared with CK in the two years. In addition, T4 guaranteed the yield and moderately improved the quality of cabbage, compared with CK. Therefore, we can alternatively apply fertilization according to the purpose of capturing the highest yield or properly declining fertilizer to sustain soil texture and productivity.

Key words: Brassica oleracea var. capitata L., soil fertility, intensive production.

Substituindo $30 \%$ de fertilizante químico por orgânico aumenta a eficiência, o rendimento e a qualidade do repolho na produção intensiva em campo aberto

RESUMO: A aplicação combinada de fertilizante químico e o orgânico é uma forma eficaz de melhorar a fertilidade do solo, o rendimento e a qualidade da colheita. Neste estudo, um experimento de campo foi conduzido para avaliar o rendimento, a qualidade e a eficiência do uso de fertilizantes em repolho (Brassica oleracea var. Capitata L.) cultivado sob diferentes proporções de fertilizante orgânico em substituição ao químico a uma taxa de $225 \mathrm{~kg} \mathrm{~N}$ ha-l em 2019 e 2020. Os tratamentos de fertilizantes incluíram N0 (fertilizante sem nitrogênio), CK (apenas fertilizante composto foi aplicado, $N: P: K=15,0 \%: 6,5 \%: 12,4 \%$ ), T1, T2 e T3 (fertilizante orgânico substituido 15\%, 30\% e 45\% de fertilizante químico, respectivamente) e T4 (a entrada total de nutrientes foi reduzida em 10\% em T2). Os resultados mostraram que o T2 apresentou o maior rendimento comercial e eficiencia no uso de fertilizantes, bem como a melhor qualidade. O rendimento comercializável, teor de vitamina $C$, teor de açúcar solúvel, REN (eficiência de absorção aparente de fertilizante N) e AEN (eficiência de uso de N agronômico) de T2 aumentaram 32,2\%, 14,9\%, 5,5\%, 97\% e 55,6\%, respectivamente, em contraste, as fibras brutas diminuíram 34,0\%, em comparação com a CK nos dois anos. Além disso, o T4 garantiu o rendimento e melhorou moderadamente a qualidade do repolho, em comparação com o CK. Portanto, podemos alternativamente aplicar fertilização de acordo com o objetivo de obter o maior rendimento ou fertilizante em declínio adequado para sustentar a textura e a produtividade do solo.

Palavras-chave: Brassica oleracea var. capitata L., fertilidade do solo, produção intensiva.

\section{INTRODUCTION}

Vegetables play an important role in many diets and toward human health and improve quality of life particularly in developing countries (BONOMI et al., 2019; SOURI et al., 2018). Economic growth and higher living standards are important incentives for increased vegetable roles in the human diet (SOURI et al., 2019). Cabbage (Brassica oleracea var. capitata L.) is an important fresh vegetable crop and plays an important role in different diets and human health in many countries, owing to its high nutritive value, which is abundant in fibers, vitamins, polyphenols and flavonoids, especially as a main source of glucosinolates (FAN et al., 2017; MARTINA et al., 2010). In addition, cabbage is a leafy vegetable that needs a large amount of fertilizer. In vegetable cultivation such as cabbage fields, high 
rates of chemical fertilization particularly nitrogen fertilizers as well as irrigation are generally applied to achieve high yields (SOURI, 2016; NAIJI and SOURI, 2018). However, only a small part of the applied fertilizer is taken up by cabbage and most of it remains in the soil or loses through various pathways (GAO et al., 2017; SMITH and HADLEY, 1989). Furthermore, excessive nitrogen (N) fertilizers could decrease the yield and quality of cabbage, reduce nitrogen use efficiency, and increase soil salinity or acidification (EVERAARTS and BOOI, 2000; SOURI et al., 2017), increase the accumulation of nitrate content and heavy metals in cabbage (FAN et al., 2017), and bring about environmental pollution by soil nitrate leaching and runoff losses (JU et al., 2011; UNLU et al., 2008; KUSCU et al., 2014). Many studies have shown that the long-term intensive cultivation of vegetables seriously destroys the soil texture, reduces the soil fertility and changes the abundance of microbes in the soil (LI et al., 2019; RUAN et al., 2013; DUBOS et al., 2017). Therefore, an effective fertilizer management method to improve soil fertility and the yield and quality of cabbage is urgently needed.

Organic fertilizer represents a more sustainable source of soil and crop fertilization mainly due to the gradual and slow release rate of mineral nutrients compared to chemical fertilizers (SOURI and HATAMIAN, 2019; NAJARIAN and SOURI, 2020). Moreover, organic fertilizers are rich in amino acids, protein, fat, humic acid and other organic nutrients, which can be directly absorbed or decomposed by the root system as an important nutrient source of vegetable crops (CHEN and HAMORI, 2009). The high content of carbon in organic fertilizers provides a suitable habitat and enough energy for flourishing the soil microorganisms and their activity toward better soil fertility (SOURI et al., 2018; SOURI et al., 2019). The application of organic fertilizers could promote crop growth and soil physical and chemical properties, and improve $\mathrm{N}$ use efficiency (CERONIO et al., 2012; MALTAS et al., 2013). However, owing to its slow nutrient release, large consumption and high labor cost, organic fertilizer has not to been widely accepted by farmers in the intensive production of vegetables. In this scenario, the combination of organic fertilizer and chemical fertilizer may be a way of fertilizer management to ensure cabbage yield and soil fertility. Many studies have shown that the combined application of organic and inorganic fertilizers could improve soil microbial activity, fertilizer use efficiency, crop yield and quality (CHIRINDA et al.,
2010; GAI et al., 2018). The combination of chemical fertilizer and organic fertilizer significantly improved plant growth, the number of trusses and fruits per plant, marketable fruit yield and fruit P, K, Ca and $\mathrm{Na}$ contents of tomato (Solanum lycopersicum) (TINDALL, 2000). A study found that the application of organic fertilizer can improve the diversity of soil microorganisms, and the combined application of an appropriate proportion of chemical fertilizer can significantly improve the yield and quality of cucumber (TONFACK et al., 2009). Reduction in chemical fertilization and its supplementation with organic fertilizers in melon (Cucumis melo L.), eggplant (Solanum melongena) and fruit, bean (Phaseolus spp.), lettuce (Lactuca sativa L.), Chinese cabbage (Brassica pekinensis L.), mustard (Brassica juncea $L$.) and other leafy vegetables (RONG et al., 2018; NARAYANAMMA et al., 2010; HERENCIA et al., 2011) had been researches, which also has been shown to have positive effects on plant, soil and environmental aspects.

However, the effect of the combined application of organic fertilizer and chemical fertilizer on the yield and quality of cabbage has rarely been reported. Moreover, as one of the main vegetableproducing areas in China, the Dongting Lake area has been intensively cultivated (high density, high water and fertilizer input and high multiple cropping index) with vegetables in the open field throughout the year. Therefore, the objective of this study was to explore the effects of different proportions of organic fertilizer substitution chemical fertilizer on the yield, quality and fertilizer utilization efficiency of cabbage and soil nutrients based on the same application rate of $\mathrm{N}$, phosphorus $(\mathrm{P})$ and potassium $(\mathrm{K})$.

\section{MATERIALS AND METHODS}

\section{Experimental site and materials}

The experiment was carried out from March to June during the cabbage growing seasons of 2019 and 2020 in the Agricultural Bureau Experimental Base $\left(28^{\circ} 54^{\prime} \mathrm{N}, 111^{\circ} 57^{\prime}\right.$ E), Hanshou County, Changde city of Hunan Province, China. The soil texture of the test site was clay loam, and this site has been intensively planted for more than 10 years for intensive cultivation of cabbage. The upper $20 \mathrm{~cm}$ soil of the experimental field contained $1.33 \mathrm{~g} \mathrm{~kg}^{-1}$ total $\mathrm{N}$ content, $0.763 \mathrm{~g} \mathrm{~kg}^{-1}$ total $\mathrm{P}$ content, $21.8 \mathrm{~g}$ $\mathrm{kg}^{-1}$ total $\mathrm{K}$ content, $40.1 \mathrm{mg} \mathrm{kg}^{-1}$ available $\mathrm{P}, 86.0 \mathrm{mg}$ $\mathrm{kg}^{-1}$ available $\mathrm{K}, 74.0 \mathrm{mg} \mathrm{kg}^{-1}$ alkali-hydrolized $\mathrm{N}$, $19.7 \mathrm{~g} \mathrm{~kg}^{-1}$ organic matter, a $\mathrm{C} / \mathrm{N}$ ratio of 14.98 and a $\mathrm{pH}$ of 7.23 . The selected cultivar was Jiegan 13349 
(Jewelry, China). The tested fertilizers included urea (N $46 \%$ ), potassium sulfate (K $41.5 \%$ ), and calcium superphosphate (P $5.2 \%$ ). Compound fertilizer is a kind of commercial fertilizer which were composed of $\mathrm{N}, \mathrm{P}$ and $\mathrm{K}$ by chemical processes $(\mathrm{N}-\mathrm{P}-\mathrm{K}=15.0$ $\%-6.5 \%-12.4 \%$ ). These fertilizers were purchased from local farm supply stores, and organic fertilizer is the downstream product by co-composting of manure and crop straw according to the protocol of organic fertilizer (Agricultural Standard of the People's Republic of China, NY 525-2012), which is produced by Changsha Haobo Biotech. Co. Ltd. The moisture, $\mathrm{N}, \mathrm{P}$, and $\mathrm{K}$ contents were $30 \%, 1.5 \%, 1.1 \%$, and 1.2 $\%$, respectively.

\section{Experimental design}

The experiment was arranged in a randomized complete block design using three replicates, six fertilizer treatments were set up in the experiment (Table 1), including N0 (without nitrogen fertilizer but applied with $\mathrm{P}$ and $\mathrm{K}$ (calcium superphosphate and potassium sulfate)), CK (the treatment of only apply compound fertilizer: the ratio of N, P, K is $15 \%: 6.5 \%: 12.4 \%$ ), T1, T2 and T3 was the treatment of organic fertilizer replacing $15 \%, 30$ $\%$ and $45 \%$ chemical fertilizer (calculated according to pure $\mathrm{N}$ concentration, the insufficient nutrients were balanced by adding corresponding chemical fertilizer), respectively, and T4 (the treatment of $30 \%$ organic fertilizer replacing chemical fertilizer, and 10 $\%$ reduction of $\mathrm{N}, \mathrm{P}$ and $\mathrm{K}$ in the whole growth period). Each plot was $24 \mathrm{~m}^{2}\left(2^{*} 12 \mathrm{~m}\right)$, and planted with $66 \mathrm{~cm}$ row spacing and $50 \mathrm{~cm}$ plant spacing. The cabbage seedlings were raised on March 10 and transplanted on April 16 in both years. Opened land was sun exposed for one week and then harrowed, plowed and cross-plowed after obtaining good topsoil. The base fertilizer was applied and the plastic film was mulched at the time of final land preparation before transplanting, and topdressing was carried out on 22nd May. For details on the split application proportions, please see the table 1. Irrigation was implemented as per local farmers' traditional irrigation methods. The plants were irrigated between the rows for four times throughout the growth season. Disease control practices were implemented according to traditional methods of local farmers.

\section{Determination of the yield and contents of $N, K$ and $P$ in cabbage}

At maturity (26 June in both years), cabbage was harvested, the head number, aboveground biomass and marketable yield were measured (including only head cabbage). Moreover, five plants were selected randomly as the sample from each unit plot, and then divided into two parts to further determine the $\mathrm{N}, \mathrm{P}$, $\mathrm{K}$ and qualities after washing and cutting into pieces. One part of the fresh samples was oven-dried for 30 min at $105^{\circ} \mathrm{C}$, and then dried to constant weight at 85 ${ }^{\circ} \mathrm{C}$. A plant micropowder prototype was used to crush the dry samples and the powder was used to determine the total $\mathrm{N}, \mathrm{K}$ and $\mathrm{P}$ contents. All dried samples were ground and then digested by $\mathrm{H}_{2} \mathrm{SO}_{4}(98 \%)$ and $\mathrm{H}_{2} \mathrm{O}_{2}$ $(30 \%)$ in an open digestion furnace at a temperature

Table 1 - Descriptions of the treatments of difference ratio of organic fertilizer replace chemical fertilizer.

\begin{tabular}{|c|c|c|c|c|c|c|c|c|c|c|c|}
\hline \multirow[t]{3}{*}{ Treatment } & \multicolumn{5}{|c|}{ 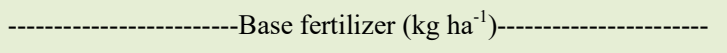 } & \multicolumn{2}{|c|}{ Topdressing $\left(\mathrm{kg} \mathrm{ha}^{-1}\right)$} & \multicolumn{4}{|c|}{--Total nutrient input $\left(\mathrm{kg} \mathrm{ha}^{-1}\right)--$} \\
\hline & $\begin{array}{l}\text { Organic } \\
\text { fertilizer }\end{array}$ & -------------. & -----Ino & anic fertilizer----- & -------- & -Inorge & fertilizer- & -------- & -N-------- & $\mathrm{P}$ & $\mathrm{K}$ \\
\hline & & $\begin{array}{l}\text { Compound } \\
\text { fertilizer }\end{array}$ & Urea & $\begin{array}{c}\text { Calcium } \\
\text { superphosphate }\end{array}$ & $\begin{array}{l}\text { Potassium } \\
\text { sulphate }\end{array}$ & Urea & $\begin{array}{l}\text { Potassium } \\
\text { sulphate }\end{array}$ & $\begin{array}{l}\text { Organic } \\
-\mathrm{N}\end{array}$ & $\begin{array}{c}\text { Inorganic } \\
-\mathrm{N}\end{array}$ & & \\
\hline N0 & 0 & 0 & 0 & 1875.0 & 405.0 & 0 & 45 & 0 & 0 & 98.2 & 186.7 \\
\hline CK & 0 & 1500.0 & 0 & 0 & 0 & 0 & 0 & 0 & 225.00 & 98.2 & 186.7 \\
\hline $\mathrm{T} 1$ & 3214.5 & 1125.0 & 0 & 0 & 0 & 48.9 & 45 & 33.75 & 191.25 & 98.2 & 186.7 \\
\hline $\mathrm{T} 2$ & 6429.0 & 750.0 & 48.9 & 0 & 45.0 & 48.9 & 45 & 67.5 & 157.5 & 98.2 & 186.7 \\
\hline $\mathrm{T} 3$ & 9643.5 & 375.0 & 97.8 & 0 & 90.0 & 48.9 & 45 & 101.25 & 123.75 & 98.2 & 186.7 \\
\hline $\mathrm{T} 4$ & 5790.0 & 675.0 & 39.6 & 0 & 36.0 & 48.9 & 45 & 60.75 & 141.75 & 88.4 & 168.0 \\
\hline
\end{tabular}

Note: N0: the treatment of non-nitrogen fertilizer; CK: the control of only apply compound fertilizer; T1, T2 and T3: the treatment of organic fertilizer replace $15 \%, 30 \%$ and $45 \%$ chemical fertilizer (calculated according to pure nitrogen content), respectively; T4: under the condition of reducing $10 \%$ of total nutrient input, organic fertilizer replace $30 \%$ chemical fertilizer. The contents of water, $\mathrm{N}$, P and $\mathrm{K}$ are $30 \%, 1.5 \%, 1.1 \%$ and $1.2 \%$ in organic fertilizer, respectively; the content of $\mathrm{N}$ in urea and $\mathrm{K}_{2} \mathrm{O}$ content in potassium sulfate is $46 \%$ and $50 \%$, respectively. Compound fertilizer is potassium sulfate compound fertilizer and the ratio of N, $\mathrm{P}, \mathrm{K}$ is $15 \%: 6.5 \%: 12.4 \%$. 
of $380{ }^{\circ} \mathrm{C}$ (VITKAR et al., 2007). In the digestion solution, the $\mathrm{N}$ concentration was determined by the semimicro Kjeldahl method, the P concentration was determined by the molybdate colorimetric method, and the $\mathrm{K}$ concentration was determined by a flame photometer. $\mathrm{N}, \mathrm{P}$, and $\mathrm{K}$ absorption per unit area was calculated based on aboveground biomass and cabbage N, P, and $\mathrm{K}$ concentrations. Furthermore, the $\mathrm{RE}_{\mathrm{N}}$ (apparent uptake efficiency of fertilizer $\mathrm{N}$ ), $\mathrm{N}_{(\mathrm{P} \text { or K })} \mathrm{UE}_{\mathrm{g}}(\mathrm{N}, \mathrm{P}$ or K use efficiency for marketable production), $\mathrm{N}_{\left(\mathrm{P}_{\text {or K}}\right)} \mathrm{UE}_{\mathrm{b}}$ (N use efficiency for biomass production), $\mathrm{AE}_{\mathrm{N}}$ (agronomic $\mathrm{N}$ use efficiency) and $\mathrm{PFP}_{\mathrm{N}, \mathrm{P}, \mathrm{K}}$ (partial factor productivity of fertilizer $\mathrm{N}, \mathrm{P}$ or $\mathrm{K}$ ) were calculated by the following formulas:

$\mathrm{RE}_{\mathrm{N}}=100 *\left(\mathrm{~N}_{\mathrm{T}}-\mathrm{N}_{\mathrm{N} 0}\right) /$ Fertilizer N input $(\%)$;

Among them, $\mathrm{N}_{\mathrm{T}}$ represents the total $\mathrm{N}$ content of cabbage under the CK, T1, T2, T3 or T4 treatments, and $\mathrm{N}_{\mathrm{N} 0}$ represents the total $\mathrm{N}$ content of cabbage under N0 treatment.

$\mathrm{AE}_{\mathrm{N}}=\left(\mathrm{Y}_{\mathrm{T}}-\mathrm{Y}_{\mathrm{N} 0}\right) /$ Fertilizer Ninput $\left(\mathrm{kgkg}^{-1}\right)$;

Among them, $\mathrm{Y}_{\mathrm{T}}$ represents the marketable yield under the CK, T1, T2, T3 or T4 treatments, and $\mathrm{Y}_{\mathrm{N} 0}$ represents the marketable yield of cabbage under the N0 treatment.

$\mathrm{N}_{(\mathrm{P} \mathrm{or} \mathrm{K})} \mathrm{UE}_{\mathrm{g}}=$ Marketable yield/Total N, P or K uptake $\left(\mathrm{kg} \mathrm{kg}^{-1}\right)$;

$\mathrm{N}_{(\mathrm{P} \text { or K)UEb }}=$ Aboveground biomass/Total $\mathrm{N}, \mathrm{P}$ or $\mathrm{K}$ uptake $\left(\mathrm{kg} \mathrm{kg}^{-1}\right)$;

$\mathrm{PFP}_{\mathrm{N}, \mathrm{P} \text { or K}}=$ Marketable yield/Fertilizer N, P or K input $\left(\mathrm{kg} \mathrm{kg}^{-1}\right)$.

\section{Determination of soil chemical properties}

The upper $20 \mathrm{~cm}$ of soil was collected and dried at room temperature before transplanting and after harvesting, it was passed through a $2 \mathrm{~mm}$ sieve after being ground for further analysis. The total $\mathrm{N}$, total $\mathrm{P}$, and total $\mathrm{K}$ were measured throughout the semi-micro Kjeldahl method, the molybdate colorimetric method after perchloric acid digestion, and the flame photometry method after melting with sodium hydroxide, respectively. The $\mathrm{pH}$, organic matter, alkali-hydrolyzed nitrogen, available phosphorus and available potassium were determined by conventional methods (THOMAS et al., 1967).

\section{Quality determination of cabbage}

The residual fresh samples were homogeneously smashed with a juice machine. The contents of vitamin $\mathrm{C}\left(\mathrm{V}_{\mathrm{C}}\right)$, crude fiber and soluble sugar were measured immediately. Briefly, the Vc content was determined using the spectrophotometer method at a wavelength of $230 \mathrm{~nm}$. The crude fiber content was determined by the acid-base digestion method (National Standard of the People's Republic of China, GB/T 5009.10-2003). The soluble sugar concentration was determined by a colorimetric method using anthrone reagent at $620 \mathrm{~nm}$ and a microplate reader (Nano Quant, infinite M200, Tecan, Switzerland) (Hampel, 1950).

\section{Data analysis}

Data were processed with Microsoft Excel 2016, and the analysis of variance was performed using Statistix 9.0 software. The differences between treatments were compared using the least significance difference (LSD) test at 0.05 probability levels. The Sigmaplot 10.0 was used for graphical presentation of the data.

\section{RESULTS}

Effects of fertilization treatments on soil chemical properties after cabbage harvesting

Different fertilization treatments significantly affected the soil chemical properties, and the trend was consistent between the two years. The total $\mathrm{P}$ content, available $\mathrm{P}$ content and organic matter content of the treatments with organic fertilizer replaced with chemical fertilizer (T1-T4) increased by $16.8 \%, 24.3 \%$, and $10.9 \%$ and $-2.2 \%, 20.0 \%$, and $5.2 \%$, respectively, compared with those of CK in 2019 and 2020 (Table 2). The available K content of T1-T4 was significantly decreased by $47.7 \%$ in 2019 and $36.1 \%$ in 2020 compared with the CK treatment. The $\mathrm{N}$ application treatment (CK and T1-T4) significantly increased the contents of total nitrogen, alkali-hydrolized $\mathrm{N}$, organic matter and available $\mathrm{P}$ after cabbage harvesting compared with N0.

The total $\mathrm{P}$, available $\mathrm{P}$ and organic matter content of T3 increased by $13.1 \%, 41.3$ $\%, 35.1 \%$ and $3.2 \%, 28.6 \%, 9.5 \%$ in 2019 and 2020, respectively, compared with CK. There was no significant difference between T1, T4 and CK in the total $\mathrm{N}, \mathrm{K}$, and $\mathrm{P}$ contents, organic matter content, alkali-hydrolized $\mathrm{N}$ content, or available $\mathrm{P}$ and $\mathrm{K}$ contents after cabbage harvesting. While the available $\mathrm{K}$ was significantly decreased. Although the total $\mathrm{P}$ and available $\mathrm{K}$ contents were significantly decreased, the others were not significantly different between $\mathrm{T} 2$ and $\mathrm{CK}$.

\section{Effects of treatments on the yield and its components of cabbage}

The highest aboveground biomass and marketable yield of cabbage were observed in $\mathrm{T} 2$, and the result was consistent between the two years 
Table 2 - Effects of combined application of organic and chemical fertilizers on soil nutrients after cabbage harvesting.

\begin{tabular}{|c|c|c|c|c|c|c|c|c|}
\hline Year & Treatment & $\begin{array}{c}\text { Total N } \\
\text { content } \\
(\mathrm{g} / \mathrm{kg})\end{array}$ & $\begin{array}{c}\text { Total P } \\
\text { content } \\
(\mathrm{g} / \mathrm{kg})\end{array}$ & $\begin{array}{c}\text { Total K } \\
\text { content } \\
(\mathrm{g} / \mathrm{kg})\end{array}$ & $\begin{array}{l}\text { Organic matter } \\
\text { content }(\mathrm{g} / \mathrm{kg})\end{array}$ & $\begin{array}{c}\text { Alkali- } \\
\text { hydrolized- } \\
\text { N (mg/kg) }\end{array}$ & $\begin{array}{c}\text { Available P } \\
\text { content } \\
(\mathrm{mg} / \mathrm{kg})\end{array}$ & $\begin{array}{c}\text { Available K } \\
\text { content } \\
(\mathrm{mg} / \mathrm{kg})\end{array}$ \\
\hline \multirow[t]{7}{*}{2019} & No & $1.12 \mathrm{~b}$ & $1.55 \mathrm{ab}$ & $21.20 \mathrm{a}$ & $12.37 \mathrm{c}$ & $82.0 \mathrm{~b}$ & $60.9 \mathrm{c}$ & $155.7 \mathrm{~b}$ \\
\hline & CK & $1.37 \mathrm{a}$ & $1.28 \mathrm{~b}$ & $21.03 \mathrm{a}$ & $15.30 \mathrm{~b}$ & $134.0 \mathrm{a}$ & $192.0 \mathrm{~b}$ & $257.0 \mathrm{a}$ \\
\hline & $\mathrm{T} 1$ & $1.41 \mathrm{a}$ & $1.52 \mathrm{ab}$ & $21.10 \mathrm{a}$ & $15.40 \mathrm{~b}$ & $119.0 \mathrm{a}$ & $231.7 \mathrm{ab}$ & $136.7 \mathrm{bc}$ \\
\hline & $\mathrm{T} 2$ & $1.39 \mathrm{a}$ & $1.38 \mathrm{ab}$ & $20.08 \mathrm{~b}$ & $15.67 \mathrm{~b}$ & $124.3 \mathrm{a}$ & $233.7 \mathrm{ab}$ & $144.0 \mathrm{bc}$ \\
\hline & $\mathrm{T} 3$ & $1.49 \mathrm{a}$ & $1.72 \mathrm{a}$ & $20.27 \mathrm{ab}$ & $20.67 \mathrm{a}$ & $126.7 \mathrm{a}$ & $271.3 \mathrm{a}$ & $124.0 \mathrm{c}$ \\
\hline & $\mathrm{T} 4$ & $1.33 \mathrm{a}$ & $1.36 \mathrm{ab}$ & $20.57 \mathrm{ab}$ & $16.20 \mathrm{~b}$ & $124.0 \mathrm{a}$ & $217.7 \mathrm{ab}$ & $133.0 \mathrm{bc}$ \\
\hline & Mean & $1.35 \mathrm{~A}$ & $1.47 \mathrm{~A}$ & 20.7 B & $15.94 \mathrm{~B}$ & $118.3 \mathrm{~A}$ & $201.2 \mathrm{~A}$ & $158.4 \mathrm{~A}$ \\
\hline \multirow[t]{7}{*}{2020} & N0 & $1.29 \mathrm{~b}$ & $0.91 \mathrm{a}$ & $27.97 \mathrm{a}$ & $16.77 \mathrm{~b}$ & $119.0 \mathrm{a}$ & $57.83 \mathrm{e}$ & $157.00 \mathrm{~b}$ \\
\hline & CK & $1.24 \mathrm{~b}$ & $0.93 \mathrm{a}$ & $25.40 \mathrm{a}$ & $18.47 \mathrm{~b}$ & $118.3 \mathrm{a}$ & $214.70 \mathrm{~d}$ & $186.33 \mathrm{a}$ \\
\hline & $\mathrm{T} 1$ & $1.26 \mathrm{~b}$ & $0.96 \mathrm{a}$ & $26.47 \mathrm{a}$ & $18.47 \mathrm{~b}$ & $119.3 \mathrm{a}$ & $251.63 \mathrm{abc}$ & $146.00 \mathrm{~b}$ \\
\hline & $\mathrm{T} 2$ & $1.31 \mathrm{~b}$ & $0.92 \mathrm{a}$ & $27.50 \mathrm{a}$ & $18.67 \mathrm{~b}$ & $120.0 \mathrm{a}$ & $265.27 \mathrm{ab}$ & $115.00 \mathrm{c}$ \\
\hline & $\mathrm{T} 3$ & $1.50 \mathrm{a}$ & $0.90 \mathrm{a}$ & $24.13 \mathrm{a}$ & $22.63 \mathrm{a}$ & $129.0 \mathrm{a}$ & $276.20 \mathrm{a}$ & $103.67 \mathrm{c}$ \\
\hline & $\mathrm{T} 4$ & $1.34 \mathrm{~b}$ & $0.88 \mathrm{a}$ & $24.63 \mathrm{a}$ & $17.97 \mathrm{~b}$ & $121.0 \mathrm{a}$ & $237.83 \mathrm{c}$ & $111.67 \mathrm{c}$ \\
\hline & Mean & $1.32 \mathrm{~A}$ & $0.91 \mathrm{~B}$ & $26.0 \mathrm{~A}$ & $18.56 \mathrm{~A}$ & $121.1 \mathrm{~A}$ & $217.2 \mathrm{~A}$ & $136.6 \mathrm{~A}$ \\
\hline
\end{tabular}

Note: N0: the treatment of non-nitrogen fertilizer; CK: the control of only apply compound fertilizer; T1, T2 and T3: the treatment of organic fertilizer replace $15 \%, 30 \%$ and $45 \%$ chemical fertilizer (calculated according to pure nitrogen content), respectively; T4: under the condition of reducing $10 \%$ of total nutrient input, organic fertilizer replace $30 \%$ chemical fertilizer. Different lowercase letters between the same columns represent significant at 0.05 level according to Least Significant Difference (LSD) test in same year; Different uppercase letters in the same column represent significant at 0.05 level according to Least Significant Difference (LSD) test between 2019 and 2020 .

(Table 3). The marketable yield of T2 increased by $16.1 \%$ in 2019 and $27.7 \%$ in 2020 . The yield of cabbage was not significantly different between $\mathrm{T} 1$, T3, T4 and CK. Compared with N0, the aboveground biomass and marketable yield of the organic application treatment (T1-T4) increased by $29.2 \%$ and $28.5 \%$ and $53.1 \%$ and $66.4 \%$ in 2019 and 2020 , respectively, which increased the marketable weight per plant. In addition, there were no significant differences in the harvest index $(\mathrm{HI})$ and number of cabbage headings among different treatment in 2019, while the number of cabbage headings and HI of T2 and T3 were significantly higher than those of the other treatments in 2020 .

\section{Effects of treatments on the qualities of cabbage}

The highest Vc and soluble sugar content and the lowest crude fibers were observed in T2, and the trend was consistent in both years (Figure 1). The treatments with organic fertilizer replacing chemical fertilizer (T1-T4) significantly increased the contents of $\mathrm{Vc}$ and soluble sugar, while decreasing the content of crude fibers compared with CK (Figure 1). Among them, compared with $\mathrm{CK}$, the crude fiber content of T1, T2, T3 and T4 decreased by $35.5 \%, 37.3 \%, 20.9$
$\%$ and $28.1 \%$ on average in the two years, respectively (Figure 1A). The Vc and soluble sugar content of T1, T2, T3 and T4 increased by $10.6 \%, 16.0 \%, 19.1 \%, 14.3$ $\%$ and $2.8 \%, 7.8 \%, 8.8 \%$ and $5.4 \%$ on average in the two years, respectively, as compared with CK (Figure 1B; Figure 1C). The crude fiber content, Vc content and soluble sugar content were not significantly different between T3 and T4. In addition, the crude fiber and $\mathrm{Vc}$ contents showed no differences between $\mathrm{T} 1$ and T2; however, the soluble sugar content of T2 was significantly higher than that of $\mathrm{T} 1$.

\section{Effects of treatments on fertilizer use efficiency}

The highest $\mathrm{N}$ accumulation, $\mathrm{RE}_{\mathrm{N}}, \mathrm{AE}_{\mathrm{N}}$ and $\mathrm{PFP}_{\mathrm{N}}$ were observed in T2, which were significantly higher than that those in CK and N0 (Tables 4, Figure 2). However, there were no significant differences in $\mathrm{N}$ accumulation, $\mathrm{RE}_{\mathrm{N}}, \mathrm{AE}_{\mathrm{N}}, \mathrm{NUE}_{\mathrm{g}}, \mathrm{NUE}_{\mathrm{b}}$ or $\mathrm{PFP}_{\mathrm{N}}$ between T1, T3, T4 and CK. Compared to N0, the $\mathrm{N}$ accumulation and $\mathrm{PFP}_{\mathrm{N}}$ content of the treatments with fertilizer (CK, T1, T2, T3 and T4) were significantly increased, in contrast, the NUEg and NUEb were decreased (Table 4).

Compared with N0, the $\mathrm{K}$ accumulation and $\mathrm{PFP}_{\mathrm{K}}$ content of the fertilizer application 
Table 3 - Effects of combined application of organic and chemical fertilizers on the yield and its components of cabbage.

\begin{tabular}{|c|c|c|c|c|c|c|c|}
\hline Year & Treatment & $\begin{array}{l}\text { Aboveground } \\
\text { biomass }\left(\mathrm{t} \mathrm{ha}^{-1}\right)\end{array}$ & $\begin{array}{l}\text { Marketable } \\
\text { yield }\left(\mathrm{t} \mathrm{ha}^{-1}\right)\end{array}$ & $\begin{array}{c}\text { Number of } \\
\text { cabbage heading } \\
\left(10^{4} \mathrm{ha}^{-1}\right)\end{array}$ & $\begin{array}{c}\text { Marketable } \\
\text { weight per } \\
\text { plant (kg) }\end{array}$ & $\begin{array}{c}\text { Aboveground } \\
\text { biomass per } \\
\text { plant }(\mathrm{kg})\end{array}$ & HI (\%) \\
\hline \multirow[t]{7}{*}{2019} & No & $45.54 \mathrm{c}$ & $29.88 \mathrm{c}$ & $2.21 \mathrm{a}$ & $1.35 \mathrm{c}$ & $2.07 \mathrm{c}$ & $65.89 \mathrm{a}$ \\
\hline & CK & $57.23 \mathrm{~b}$ & $36.58 \mathrm{~b}$ & $2.25 \mathrm{a}$ & $1.63 \mathrm{~b}$ & $2.55 \mathrm{~b}$ & $63.85 \mathrm{a}$ \\
\hline & $\mathrm{T} 1$ & $59.03 \mathrm{ab}$ & $38.54 \mathrm{ab}$ & $2.26 \mathrm{a}$ & $1.70 \mathrm{~b}$ & $2.61 \mathrm{~b}$ & $65.29 \mathrm{a}$ \\
\hline & $\mathrm{T} 2$ & $61.73 \mathrm{a}$ & $42.53 \mathrm{a}$ & $2.17 \mathrm{a}$ & $1.97 \mathrm{a}$ & $2.86 \mathrm{a}$ & $68.89 a$ \\
\hline & $\mathrm{T} 3$ & $59.77 \mathrm{ab}$ & $39.02 \mathrm{ab}$ & $2.28 \mathrm{a}$ & $1.72 \mathrm{~b}$ & $2.63 \mathrm{ab}$ & $65.20 \mathrm{a}$ \\
\hline & $\mathrm{T} 4$ & $56.27 \mathrm{~b}$ & $35.52 \mathrm{~b}$ & $2.17 \mathrm{a}$ & $1.64 \mathrm{~b}$ & $2.60 \mathrm{~b}$ & $63.10 \mathrm{a}$ \\
\hline & Mean & $56.60 \mathrm{~A}$ & $37.01 \mathrm{~A}$ & $2.22 \mathrm{~A}$ & $1.67 \mathrm{~A}$ & $2.55 \mathrm{~A}$ & $65.37 \mathrm{~A}$ \\
\hline \multirow[t]{7}{*}{2020} & N0 & $41.08 \mathrm{c}$ & $27.40 \mathrm{c}$ & $2.00 \mathrm{c}$ & $1.27 \mathrm{c}$ & $2.06 \mathrm{~b}$ & $62.03 \mathrm{e}$ \\
\hline & CK & $55.54 \mathrm{~b}$ & $35.44 \mathrm{~b}$ & $2.20 \mathrm{ab}$ & $1.61 \mathrm{~b}$ & $2.52 \mathrm{a}$ & $63.74 \mathrm{de}$ \\
\hline & $\mathrm{T} 1$ & $61.84 \mathrm{ab}$ & $40.07 \mathrm{ab}$ & $2.10 \mathrm{c}$ & $1.91 \mathrm{ab}$ & $2.95 \mathrm{a}$ & $64.81 \mathrm{~cd}$ \\
\hline & $\mathrm{T} 2$ & $66.42 \mathrm{a}$ & $45.24 \mathrm{a}$ & $2.34 \mathrm{a}$ & $1.93 \mathrm{ab}$ & $2.83 \mathrm{a}$ & $68.11 \mathrm{ab}$ \\
\hline & $\mathrm{T} 3$ & $64.25 \mathrm{ab}$ & $44.53 \mathrm{a}$ & $2.24 \mathrm{ab}$ & $1.99 \mathrm{a}$ & $2.86 \mathrm{a}$ & $69.24 \mathrm{a}$ \\
\hline & $\mathrm{T} 4$ & $59.13 \mathrm{ab}$ & $39.22 \mathrm{ab}$ & $2.20 \mathrm{~b}$ & $1.78 \mathrm{ab}$ & $2.68 \mathrm{a}$ & $66.31 \mathrm{bc}$ \\
\hline & Mean & $58.04 \mathrm{~A}$ & $38.32 \mathrm{~A}$ & $2.18 \mathrm{~A}$ & $1.75 \mathrm{~A}$ & $2.65 \mathrm{~A}$ & $65.71 \mathrm{~A}$ \\
\hline
\end{tabular}

Note: N0: the treatment of non-nitrogen fertilizer; CK: the control of only apply compound fertilizer; T1, T2 and T3: the treatment of organic fertilizer replace $15 \%, 30 \%$ and $45 \%$ chemical fertilizer (calculated according to pure nitrogen content), respectively; T4: under the condition of reducing $10 \%$ of total nutrient input, organic fertilizer replace $30 \%$ chemical fertilizer. Different lowercase letters between the same columns represent significant at 0.05 level according to Least Significant Difference (LSD) test in same year; Different uppercase letters in the same column represent significant at 0.05 level according to Least Significant Difference (LSD) test between 2019 and 2020.

treatment (CK, T1, T2, T3 and T4) increased by 42.4 $\%$ and $31.3 \%$, respectively, on average (Table 4 ). The $\mathrm{K}$ accumulation and $\mathrm{PFP}_{\mathrm{K}}$ of $\mathrm{T} 2$ were increased by $52.5 \%$ and $16.3 \%$ and $18.8 \%$ and $27.6 \%$ in 2019 and 2020, respectively, compared with those of CK. There were no significant differences in $\mathrm{K}$ accumulation, $\mathrm{KUE}_{\mathrm{g}}, \mathrm{KUE}_{\mathrm{b}}$ or $\mathrm{PFP}_{\mathrm{p}}$ between $\mathrm{T} 1$, T3, T4 and CK. The highest $\mathrm{NUE}_{(\mathrm{g} \& \mathrm{~b})}$ and $\mathrm{PFP}_{\mathrm{p}}$ was obtained in T2. The PUE $\mathrm{g}_{\mathrm{g}}$ and $\mathrm{PUE}_{\mathrm{b}}$ of $\mathrm{T} 1, \mathrm{~T} 2$ and T3 were significantly increased compared with those of CK; however, there was no significant difference between $\mathrm{CK}$ and $\mathrm{T} 4$. There were no significant differences in $\mathrm{PFP}_{\mathrm{p}}$ between T1, T3, T4 and CK.

\section{DISCUSSION}

Soil nutrient absorption and utilization of $N, P$, and $K$ Many studies have shown that the combined application of organic $\mathrm{N}$ and chemical fertilizer could help to improve soil chemical properties (GAI et al., 2018; HERENCIA et al., 2011, ZHAO et al. 2016). BODRUZZAMAN et al. (2010) and CHOUDHARY and SURI (2009) reported that combined application of organic fertilizer and chemical fertilizer significantly increased total $\mathrm{N}$ and
$\mathrm{P}$, organic matter content and available $\mathrm{N}, \mathrm{P}$ and $\mathrm{K}$ content in soil after the harvest of cabbage. These findings were in conformity with our results (Table 2 ). In addition, with the increase in the proportion of organic fertilizer replacing chemical fertilizer, the content of organic matter in soil increased gradually (Table 2). Previous studies indicated that long-term combined application of inorganic fertilizer and organic fertilizer increased the organic matter content in soil, which mainly resulted from the increase in the microbial $\mathrm{C}$ and $\mathrm{N}$ or $\mathrm{C} / \mathrm{N}$ ratio of the soil microbial biomass (HAO et al., 2008; CHANG et al., 2014). Therefore, the increase in organic matter contents under the application organic fertilizer treatment may be related to an increase in the labile organic carbon and $\mathrm{C} / \mathrm{N}$ in the soil. Furthermore, some research indicated that the combined application of inorganic fertilizer and organic fertilizer improved the soluble and exchangeable $\mathrm{K}$ in the soil profile (HABIB et al., 2014). In this study, compared with $\mathrm{CK}$, the available $\mathrm{K}$ content of $\mathrm{T} 2$ in soil was significantly decreased (Table 2). This indicated that there was more $\mathrm{K}$ available for cabbage to absorb in soil before cabbage planting, and $\mathrm{K}$ was available for cabbage to absorb in soil before planting. Moreover, 


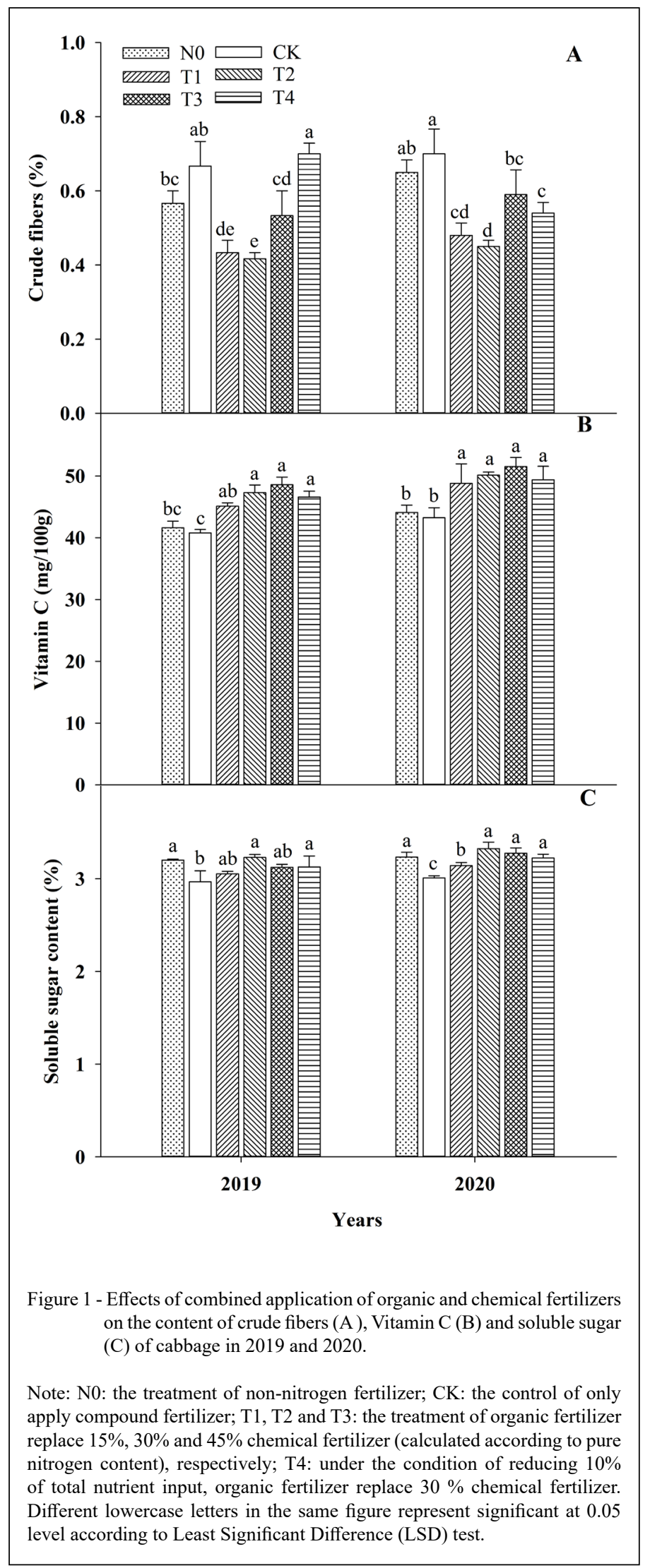

Ciência Rural, v.52, n.7, 2022. 
the available $\mathrm{K}$ content of $\mathrm{T} 2$ after harvesting was significantly increased as compared with that before the experiment. The same result was observed in PENG and WANG (2009). Therefore, the most of $\mathrm{K}$ was accumulated by cabbage. This is one of the reasons that $\mathrm{T} 2$ has the highest $\mathrm{PFP}_{\mathrm{K}}$. Finally, the total $\mathrm{P}$, available $\mathrm{P}$ and organic matter content of $\mathrm{T} 3$ were significantly increased compared to those of CK, T1, T2 and T4 (Table 2). Our data were consistent with ZHAO and ZHOU (2011), which indicated that increasing the proportion of organic fertilizer replacement chemical fertilizer was beneficial to improving soil fertility. However, the highest yield of cabbage was observed not in T3, but in T2 (Table 3), which may be due to the slower release of organic fertilizer nutrients not helping to absorb short growth period plants, and the surplus nutrients remained in the soil (SOURI et al., 2018 and 2019b). In addition, the reasons need to be further explored.

Compared with CK, T2 significantly increased the $\mathrm{RE}_{\mathrm{N}}, \mathrm{AE}_{\mathrm{N}}, \mathrm{PFP}_{\mathrm{N}, \mathrm{PandK}}$ and $\mathrm{N}$ accumulation of cabbage, however, there were no significant differences between T1, T3, T4 and CK (Table 4; Figure 2). From the equation, the main reason was that T2 significantly increased the marketable yield and the aboveground biomass of cabbage. A previous study indicated that replacing $10 \%$ chemical fertilizer with organic fertilizer significantly increased the chlorophyll content, enhanced the photosynthesis and promoted the yield of lettuce, as compared with chemical fertilizer application (WU et al., 2014). Similar results were observed in cabbage and wheat, in which, the treatment of organic fertilizer replacing chemical fertilizer improved the photosynthesis and yield (NIE et al., 2014; SAIKIA et al., 2015). This may be one of the reasons for the high aboveground biomass and marketable yield of T2. Studies have shown that long-term combination application of organic fertilizer and chemical fertilization significantly increases soil organic carbon, organic nitrogen, phospholipid fatty acid profiles, enzyme activities and the relative abundances of the microbial community (GAI et al., 2018; HERENCIA et al., 2011). Soil enzyme activity and the relative abundances of the microbial community in soil were significantly and positively related to vegetable yields (ZHANG et al., 2018). In addition, the activities of enzymes and the relative abundances of microbial

Table 4 - Effects of combined application of organic and chemical fertilizers on fertilizer use efficiency of cabbage.

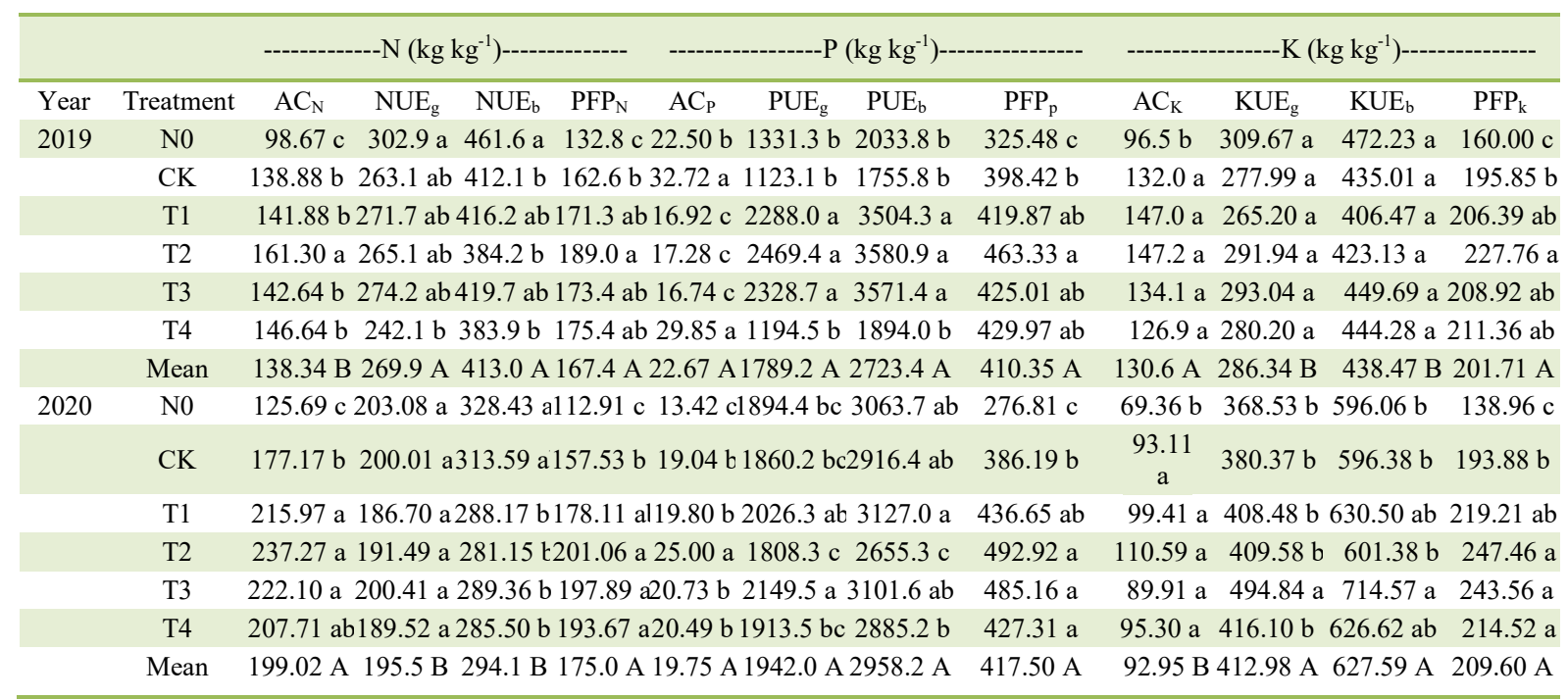

Note: N0: the treatment of non-nitrogen fertilizer; CK: the control of only apply compound fertilizer; T1, T2 and T3: the treatment of organic fertilizer replace 15\%, 30\% and 45\% chemical fertilizer (calculated according to pure nitrogen content), respectively; T4: under the condition of reducing $10 \%$ of total nutrient input, organic fertilizer replace $30 \%$ chemical fertilizer; $\mathrm{AC}_{(\mathrm{N}, \mathrm{P} \text { or K) }}\left(\mathrm{kg} \mathrm{ha}^{-1}\right)$ : represent the accumulation content of N, P or K. Different lowercase letters between the same column represent significant at 0.05 level according to Least Significant Difference (LSD) test in same year; Different uppercase letters in the same column represent significant at 0.05 level according to Least Significant Difference (LSD) test between 2019 and 2020. 
communities in soil were related to plant biomass or organic matter degradation (ZHENG et al., 2018). Other reasons for the high $\mathrm{N}$ accumulation and fertilizer use efficiency may be that the T2 treatment changed the soil structure and increased soil microorganisms, thus promoting the release of organic fertilizer nutrients and the absorption of nutrients by roots. The reasons for the high nutrient use efficiency of $\mathrm{T} 2$ need to be studied in the future.

\section{The yield and quality of cabbage}

Reasonable application of organic and chemical fertilizers is an effective way to improve crop productivity, obtain high yield and quality, and improve soil fertility (ASLANI and SOURI, 2018; BRITO et al., 2012). In this study, the results indicated that T2 significantly increased the marketable yield and aboveground biomass, and improved the quality of cabbage (crude fibers, Vc and soluble sugar), as compared with CK (Table 3; Figure 1). This findings was consistent with YANG et al. (2018), who used $30 \%$ organic fertilizer to replace inorganic fertilizer and significantly increased the yield and quality of spring cabbage under the same N, P and K application rates compared with the treatment with only chemical fertilizer. It has been shown that an integrated

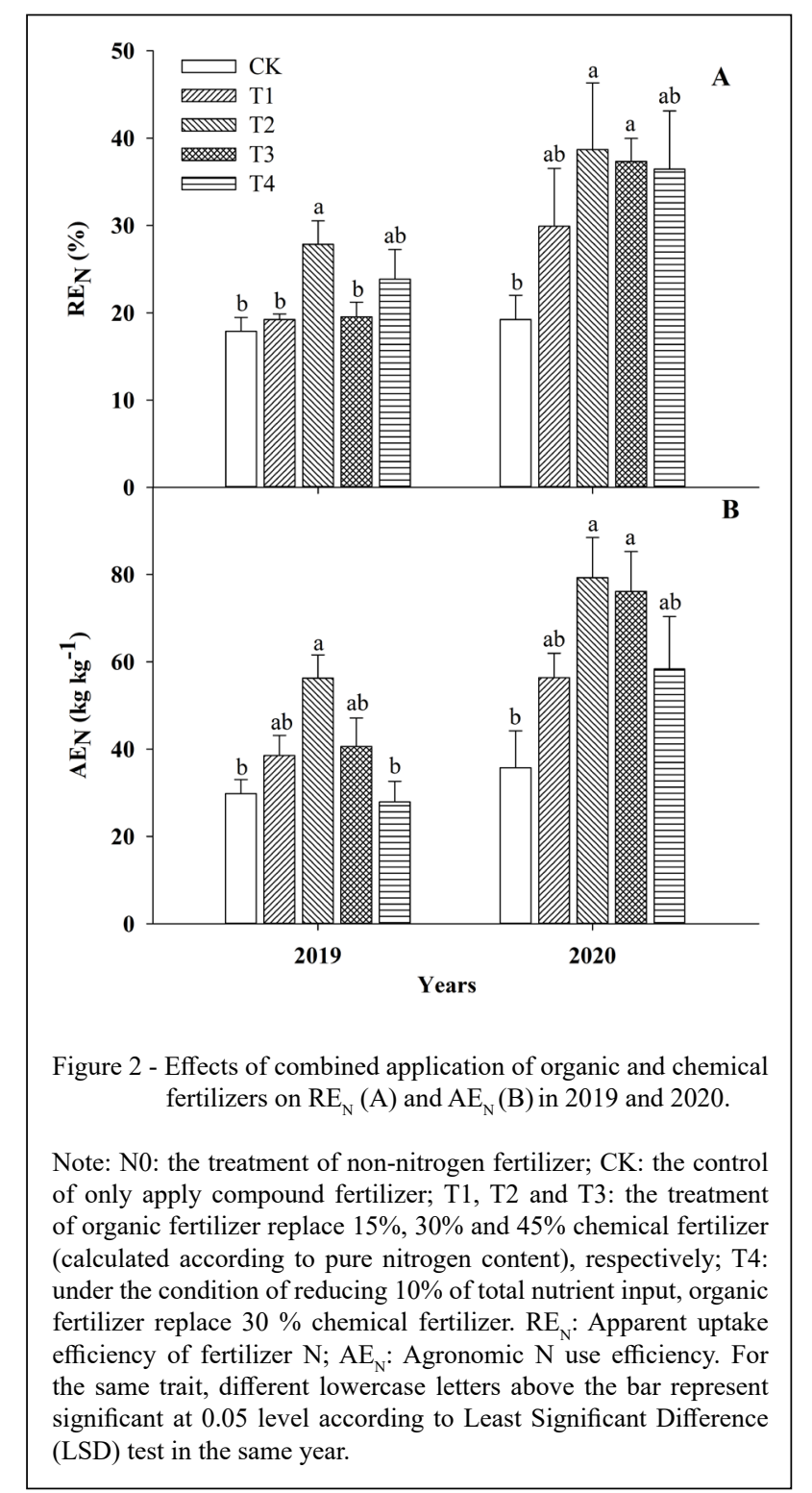

Ciência Rural, v.52, n.7, 2022. 
approach of the combined application of chemical fertilizers and organic fertilizers such as cow manure or plant residue can significantly increase soil mineral bioavailability and plant productivity (SOURI et al., 2018 and 2019b; ZARGAR SHOOSHTARI et al., 2020). Moreover, the results also showed that T1, T3 and T4 significantly increased the content of $\mathrm{Vc}$ and soluble sugar, and significantly decreased the content of crude fibers, compared with CK. However, there was no significant difference in the marketable yield between T1, T3, T4 and CK (Tables 2, 3; Figure 1). The highest yield and quality of Chinese cabbage was obtained in the treatment with $25 \%$ organic fertilizer replacement chemical fertilizer under the same $\mathrm{N}, \mathrm{P}$ and $\mathrm{K}$ application rate, while there was no significant difference in yield between $0,50,75$ and $100 \%$ alternative proportion (YE et al., 2004). However, the opposite results were observed, where no significant difference in the yield of cabbage was observed between the treatment of 20,30 and $40 \%$ organic fertilizer substitution chemical fertilizer treatments (Niu et al., 2014). This difference may be caused by the difference in soil physical and chemical properties or microbial communities in different planting areas, and the detailed reasons need to be further explored.

The aboveground biomass, marketable yield, $\mathrm{RE}_{\mathrm{N}}$ and $\mathrm{AE}_{\mathrm{N}}$ of cabbage showed no significant differences between the T4 and CK treatments (Table 2; Figure 2); however, the total nutrient input of T4 was reduced by $10 \%$ compared with that of CK (Table 1). Previous studies have shown that there were no significant differences in the economic and biological yields between treatments with different proportions of organic fertilizer replacing chemical fertilizer and local conventional fertilization treatments when the total application of fertilizer was excessive (MOE et al., 2019; YAO et al., 2010). This indicated that the local conventional fertilizer level caused a luxury waste of nutrients. Moreover, T4 significantly improved the quality of cabbage compared with $\mathrm{CK}$ (Figure 1). Hence, T4 treatment could be considered an effective and low-cost fertilization regime based on sustained yield and improved quality. The interactive effects between reduced application of fertilizer and different ratios of organic fertilizer replacing chemical fertilizer on cabbage yield, quality, fertilizer utilization efficiency and soil properties need to be further explored.

\section{CONCLUSION}

Under the fertilization regime of replacing $30 \%$ chemical fertilizer with organic fertilizer (T2) cabbage had the significantly highest yield and relatively superior quality and the fertilizer use efficiency, while reducing fertilizer (T4) guaranteed the yield and moderately improved the quality of cabbage compared with local traditional fertilization (CK). Therefore, we can alternatively fertilize according to the purposes of capturing the highest yield or properly declining fertilizer to sustain soil texture and productivity in open-field intensive production of cabbage.

\section{ACKNOWLEDGMENTS}

This research is supported by the National Key Research and Development Program of China (2018YFD0201208) and the Key Research and Development Program of Hunan Province (2017NK2374).

\section{DECLARATION OF CONFLICT OF INTEREST}

The authors declare no conflict of interest. The founding sponsors had no role in the design of the study; in the collection, analyses, or interpretation of data; in the writing of the manuscript, and in the decision to publish the results.

\section{AUTHORS' CONTRIBUTIONS}

FYP, PG and YXL conceived and coordinated the study. FYP and XWC designed the experiments. XWC and HLL obtained the data. XWC performed the statistical analyzes and drafted the manuscript. All authors critically revised the manuscript and approved of the final version.

\section{REFERENCES}

ASLANI, M.; SOURI, M. K. Growth and Quality of Green Bean (Phaseolus vulgaris L.) under Foliar Application of Organic Chelate Fertilizers. Open Agriculture. v.3, p.146-154, 2018. Available from: <https://www.sci-hub.ren/10.1515/opag-20180015>. Accessed: May, 2018. doi: 10.1515/opag-2018-0015.

BODRUZZAMAN, M. et al. Long-term effects of applied organic manures and inorganic fertilizers on yield and soil fertility in a wheat-rice cropping pattern. Proceedings of the 19th World Congress of Soil Science: Soil solutions for a changing world, Brisbane, Australia, 1-6 August 2010. Symposium 2.2.2 Dynamics of organic material in soils 2010, p.142-145, 2010. Available from: $<$ https://www.iuss.org/19th\%20WCSS/Symposium/pdf/0271. pdf $>$. Accessed: Aug. 6, 2010.

BONOMI, S. et al. ICT in a Collaborative network to Improve Quality of Life: A Case of Fruit and Vegetables Reuse: Schriftenreihe der Filmuniversitt Babelsberg KONRAD WOLF[M]// Poesie des Alltäglichen. p.51-67, 2019. Available from: $\quad<$ https://www.researchgate.net/publication/331085442>. Accessed: Jan. 15, 2019. doi: 10.1007/978-3-030-10737-6_4.

BRITO, L. M. et al. Yield and nitrogen uptake of white cabbage (Brassica oleracea var. capitata) with organic and inorganic 
fertilisers. Acta Horticulturae, v.933, p.107-113, 2012. Available from: <10.17660/ActaHortic.2012.933.11>. Accessed: Mar. 6 , 2010. doi: 10.17660/ActaHortic.2012.933.11.

CHANG, E. H., et al. Effects of long-term treatments of different organic fertilizers complemented with chemical $\mathrm{n}$ fertilizer on the chemical and biological properties of soils(soil fertility). Soil science and plant nutrition, v.60, n.4, 499-511, 2014. Available from: <https://www.sci-hub.ren/10.1080/00380768.2014.917333> . Accessed: Jun. 18, 2014. doi: 10.1080/00380768.2014.917333.

CHEN, G.; HAMORI, S. Solution to the dilemma of the migrant, labor shortage and the rural labor, surplus in China. China World Economy. v.4, p.53-71. Available from: $<$ https://www. researchgate.net/publication/46538705>. Accessed: Jul. 4, 2010. doi: 10.1111/j.1749-124X.2009.01158.x.

CHIRINDA,N., etal. Soilproperties, cropproductionand greenhouse gas emissions from organic and inorganic fertilizer-based arable cropping systems. Agriculture Ecosystems and Environment, v.139, p.584-594, 2010. Available from: <https://www.ixueshu. com/document/d8e79aab5d843d7c318947a18e7f9386.html>. Accessed: Dec. 4, 2010. doi: 10.1016/j.agee.2010.10.001.

CHOUDHARY, A. K.; SURI, V. K. Effect of organic manures and inorganic fertilizers on productivity, nutrient uptake and soil fertility in rice (Oryza sativa)-wheat (Triticum aestivum) crop sequence in western Himalayas. Current Advances Agricultural Sciences, v.1 n.2, p.65-69, 2009. Available from: <https://www.researchgate.net/ publication/260250325>. Accessed: Jan. 12, 2009

DUBOS, B. et al. Excessive use of fertilizer can increase leaching processes and modify soil reserves in two Ecuadorian oil palm plantations. Experimental Agriculture, v.53, n.2, p.255-268, 2017. Available from: <https://www.researchgate. net/publication/304185940>. Accessed: Jun. 2010. doi: 10.1017/ S0014479716000363.

EVERAARTS, A. P.; BOOI, R. The effect of nitrogen application on nitrogen utilization by white cabbage (Brassica oleracea var.capitata L.) and on nitrogen in the soil at harvest. The Journal of Horticultural Science \& Biotechnology, v.75, n.6, p.705-712, 2000. Available from: <https://www.researchgate. net/publication/40151004>. Accessed: Nov. 19, 2010. doi: 10.1080/14620316.2000.11511311.

FAN, Y. et al. Accumulation characteristics and potential risk of heavy metals in soil-vegetable system under greenhouse cultivation condition in Northern China. Ecological Engineering, v.102, p.367-373, 2017. Available from: <https://www.researchgate.net/ publication/314128131>. Accessed: May, 10, 2010. doi: 10.1016/j. ecoleng.2017.02.032.

GAI, X. P. et al. Long-term benefits of combining chemical fertilizer and manure applications on crop yields and soil carbon and nitrogen stocks in North China Plain. Agriculture Water Management, n.208, p.384-392, 2018. Available from: <https:// www.researchgate.net/publication/326403753>. Accessed: Sep. 08, 2018. doi: 10.1016/j.agwat.2018.07.002.

$\mathrm{GAO}, \mathrm{N}$. et al. Interactive effects of irrigation and nitrogen fertilizer on yield, nitrogen uptake, and recovery of two successive Chinese cabbage crops as assessed using ${ }^{15} \mathrm{~N}$ isotope. Scientia Horticulturae, v.215, p.117-125, 2017. Available from: <https:// www.researchgate.net/publication/311951669>. Accessed: Jan. 13, 2017. doi: 10.1016/j.scienta.2016.12.011.
HABIB, F. et al. Potassium dynamics in soil under long term regimes of organic and inorganic fertilizer application. Soil and Environment, v.33, n.2, p.110-115, 2014. Available from: $<$ https:// www.researchgate.net/publication/288367616>. Accessed: Jan. 13, 2017.

HAMPEL, G. A new rapid method for determination of crude fibre. Zeitschrift fur Lebensmittel Untersuchung und-Forsch, v.91, n.1, p.1-7, 1950. Available from: <https://www.researchgate. net/publication/8271009>. Accessed: Aug. 18, 2018. doi: 10.1007/ BF01453838.

$\mathrm{HAO}, \mathrm{X} . \mathrm{H}$. et al. Effect of long-term application of inorganic fertilizer and organic amendments on soil organic matter and microbial biomass in three subtropical paddy soils. Nutrient Cycling in Agroecosystems, v.81, n.1, p.17-24, 2008. Available from: < https://link.springer.com/content/pdf/10.1007\%2Fs10705007-9145-z.pdf>. Accepted: Oct. 17, 2007. doi: 10.1007/s10705007-9145-z.

HERENCIA, J. F. et al. Long-term effect of organic and mineral fertilization on soil physical properties under greenhouse and outdoor management practices. Pedosphere, v.21, n.4, p.0453, 2011. Available from: <https://www.researchgate.net/ publication/229411150>. Accessed: Aug. 11, 2011. doi: 10.1016/ S1002-0160(11)60146-X.

JU, M. et al. Nitrogen balance and loss in a greenhouse vegetable system in southeastern China. Pedosphere, v.21, n.4, p.464-472, 2011. Available from: <https://www.sciencedirect.com/science/ article/pii/S1002016011601483 > . Accessed: Aug. 11, 2011. doi: 10.1016/S1002-0160(11)60148-3.

KUSCU, H. et al. Optimizing levels of water and nitrogen applied through drip irrigation for yield, quality, and water productivity of processing tomato (Lycopersicon esculentum, Mill.). Horticulture Environment and Biotechnology, v.55, p.103114, 2014. Available from: <https://link.springer.com/content/ pdf/10.1007\%2Fs13580-014-0180-9.pdf $>$. Accessed: Mar. 4, 2014. doi: 10.1007/s13580-014-0180-9.

LI, J. G. et al. Changes in soil physical and chemical characteristics in intensively cultivated greenhouse vegetable fields in North China. Soil and Tillage Research, v.195, n.104366, 2019. Available from: <https://www.sciencedirect.com/science/ article/pii/S0167198718312510>. Accessed: Dec. 05, 2019. doi: 10.1016/j.still.2019.104366.

MALTAS, A. et al. Effect of organic fertilizers and reduced-tillage on soil properties, crop nitrogen response and crop yield: Results of a 12-year experiment in Changins, Switzerland. Soil and Tillage Research, v.126, p.11-18, 2013. Available from: <https:// www.sciencedirect.com/science/article/pii/S0167198712001547>. Accessed: Jan. 12, 2013. doi: 10.1016/j.still.2012.07.012.

MARTINA, S. et al. Effect of different fertilization and irrigation practices on yield, nitrogen uptake and fertiliser use efficiency of white cabbage (Brassica oleracea var.capitata L.). Scienta Horticulturae Amsterdam, v.125, p.103-109, 2010. Available from: $\quad<$ https://www.sciencedirect.com/science/article/pii/ S0304423810001299>. Accessed: Jun. 03, 2010. doi: 10.1016/j. scienta.2010.03.017.

MOE, K et al. Effects of integrated organic and inorganic fertilizers on yield and growth parameters of rice varieties. Rice Science, v.26, n.5, p.309-318, 2019. Available from: <https://www.sciencedirect. 
com/science/article/pii/S1672630819300630>. Accessed: Sep. 12, 2019. doi: 10.1016/j.rsci.2019.08.005.

NAIJI, M.; SOURI, M. K. Nutritional value and mineral concentrations of sweet basil under organic compared to chemical fertilization. Acta scientiarum Polonorum. Hortorum cultus, v.17, n.2, p.167175, 2018. Available from: $<$ http://www.hortorumcultus. actapol.net/pub/17_2_167.pdf $>$. Accessed: May, 22, 2018. doi: 10.24326/asphc.2018.2.14.

NAJARIAN, A.; SOURI, M. K. Influence of sugar cane compost as potting media on vegetative growth, and some biochemical parameters of Pelargonium $\times$ hortorum. Journal of Plant Nutrition, v.43, n.17, p.2680-2684, 2020. Available from: <https:// www.tandfonline.com/doi/full/10.1080/01904167.2020.1783305> . Jun. 23, 2020. doi: 10.1080/01904167.2020.1783305.

NARAYANAMMA, M. et al. Influence of integrated nutrient management on the yield, nutrient status and quality of cucumber (Cucumis Sativus L.). Vegetable Science, v.37, n.1, p.61-63, 2010. Available from: $<$ http://www.indianjournals.com/ijor.aspx?target= ijor:vgt\&volume $=37 \&$ issue $=1 \&$ article $=012>$. Accessed: May, 20, 2016.

National Standard of the People's Republic of China. Determination of crude fiber in vegetable foods. GB/T 5009.102003, p.67-69, 2003. Available from: <https://www.doc88. com/p-3148950893752.html>. Accessed: Mar. 6, 2020.

NIU Z. M. et al. Effects of partial replacement of chemical fertilizer by bio-fertilizer on nutrient uptake, photosynthesis and quality of Brassica oleracea. China Desert, v.34, n.2, p.464-471, 2014. Available from: $<$ http://en.cnki.com.cn/Article en/CJFDTOTALZGSS201402023.htm>. Accessed: Mar. 18, $201 \overline{4}$.

PENG, N.; WANG, K. F. Effects of long-term integrated fertilization with organic manure and chemical fertilizers on soil nutrients. Hubei Agriculture Science, v.48, n.2, p.63-66, 2009. Available from: < http://en.cnki.com.cn/Article en/CJFDTOTALTURA200903011.htm>. Accessed: Feb. 09, 2009. doi: 10.13758/j. cnki.tr.2009.03.013.

RONG, Q. L et al. Soil microbial characteristics and yield response to partial substitution of chemical fertilizer with organic amendments in greenhouse vegetable production. Journal of Integrative Agriculture, v.17, n.6, p.1432-1444, 2018. Available from: $\quad<$ http://creativecommons.org/licenses/by-nc-nd/4.0/>. Accessed: Mar. 15, 2018. doi: CNKI:SUN:ZGNX.0.2018-06-023.

RUAN, W. B. et al. Effects of conventional and reduced $\mathrm{N}$ inputs on nematode communities and plant yield under intensive vegetable production. Applied Soil Ecology, v.66, p.48-55, 2013. Available from: <https://www.sciencedirect.com/science/ article/pii/S0929139313000061>. Accessed: Apr. 12, 2013. doi: 10.1016/j.apsoil.2013.01.004.

SAIKIA, P. et al. Organic substitution in fertilizer schedule: Impacts on soil health, photosynthetic efficiency, yield and assimilation in wheat grown in alluvial soil. Agriculture, Ecosystems \& Environment, v.203, p.102-109, 2015. Available from: $\quad<$ https://www.sciencedirect.com/science/article/pii/ S016788091500050X>. Accessed: May, 17, 2015. doi: 10.1016/j. agee.2015.02.003.

SMITH, S. R.; HADLEY, P. A comparison of organic and inorganic nitrogen fertilizers: Their nitrate- $\mathrm{N}$ and ammonium-N release characteristics and effects on the growth response of lettuce (Lactuca sativa, L. cv. Fortune). Plant Soil, v.115, n.1, p.135-144, 1989. Available from: <https://link.springer.com/ article/10.1007/BF02220704>. Accessed: Mar. 18, 1989. doi: 10.1007/BF02220704.

SOURI, M. K. Aminochelate fertilizers: the new approach to the old problem; a review. Open Agriculture, v.1, p.118-123, 2016. Available from: <https://doi.org/10.1515/opag-2016-0016>. Accessed: Jan. 20, 2016. doi: 10.1515/opag-2016-0016.

SOURI, M. K. et al. Growth and quality of cucumber, tomato, and green bean under foliar and soil applications of an aminochelate fertilizer. Hortic. Environ. Biotechnol., v.58, n.6, p.530-536, 2017. Available from: <https://link.springer.com/article/10.1007/ s13580-017-0349-0>. Accessed: Dec. 23, 2017. doi: 10.1007/ s13580-017-0349-0.

SOURI, M. K.; HATAMIAN, M. Aminochelates in plant nutrition; a review. Journal of Plant Nutrition, v.42, n.1, p.67-78, 2019a. Available from: $<$ https://doi.org/10.1080/01904167.2018.1549671 >. Accessed: Nov. 28, 2017. doi: 10.1080/01904167.2018.1549671.

SOURI, M. K. et al. Nitrogen release dynamics of a slow release urea pellet and its effect on growth, yield, and nutrient uptake of sweet basil (Ocimum basilicum L.). Journal of plant nutrition, v.42, n.6, p.604-614, 2019b. Available from: <https://www.scihub.ren/10.1080/01904167.2019.1568460>. Accessed: Mar. 23, 2019. doi: 10.1080/01904167.2019.1568460.

SOURI, M. K. et al. Effects of manure-based urea pellets on growth, yield, and nitrate content in coriander, garden cress, and parsley plants. Journal of Plant Nutrition, v.41, n.11, p.1405-1413, 2018. Available from: <https://www.sci-hub.ren/1 0.1080/01904167.2018.1454471>. Accessed: Apr. 14, 2018. doi: $10.1080 / 01904167.2018 .1454471$

THOMAS, R. L. et al. Comparison of conventional and automated procedures for nitrogen, phosphorus, and potassium analysis of plant material using a single digestion. Agronomy Journal, v.59, p.240-243, 1967. Available from: <https://doi.org/10.2134/agronj 1967.00021962005900030010x>. Accessed: Jan. 18, 1967. doi: 10.2134/agronj1967.00021962005900030010x.

TINDALL, M. Mineral and organic fertilizing in cabbage, residual effect for commercial cultivation on yield and quality performance with organic farming. Horticultura Brasileira, v.6, n.1, p.15-20, 2000 .

TONFACK, L. B. et al. Impact of organic and inorganic fertilizers on tomato vigor, yield and fruit composition under tropical andosol soil conditions. Fruits, v.64, n.3, p.167-177, 2009. Available from: $<$ https://doi.org/10.1051/fruits/2009012>. Accessed: May, 08, 2009. doi: $10.1051 /$ fruits/2009012.

UNLU, K. et al. Nitrogen fertilizer leaching from cropped and irrigated sandy soil in Central Turkey. European Journal of Soil Science, v.50, n.4, p.609-620, 2008. Available from: <https://onlinelibrary.wiley. com/doi/pdf/10.1046/j.1365-2389.1999.00260.x>. Accessed: Dec. 28 , 1999. doi: 10.1046/j.1365-2389.1999.00260.x.

VITKAR, M. N. et al. Effect of organic and inorganic fertilizers on growth and green fruit yield of chilli (Capsicum annum L.). Asian Journal of Horticulture, p.273-276, 2007. Available from: $<$ http://researchjournal.co.in/online/TAJH/TAJH\%202(2)/2_A273-276.pdf>. Accessed: Dec. 07, 2007. 
WU, J. J. et al. Effects of combined application of different organic and inorganic fertilizers on Photosynthesis and yield and quality of lettuce. Hunan Agricultural Science, v.10, p.25-27, 2014. Available from: <http://en.cnki.com.cn/Article en/CJFDTOTALHNNK201410008.htm>. Accessed: Apr. 11, 2014. doi: 10.16498/j. cnki.hnnykx.2014.10.016.

YANG, P. et al. Effects of reduction of chemical fertilizer and organic manure supplement on spring cabbage yield and quality. Journal of Agricultural Science and Technology, v.20, n.10, p.91-100, 2018. Available from: <http://en.cnki.com.cn/Article en/CJFDTotal-NKDB201810011.htm>. Accessed: Mar. 15, 2018. doi: 1013304/jnykjdb.2018.0038.

YAO, C. X. et al. Effects of fertilizing decreasing on nitrate contents, nutritional quality and biological characteristics of three vegetables. Journal of Soil and Water Conservation, v.24, n.4, p.153-156, 2010. Available from: <https://www.researchgate.net/ publication/8271009>. Accessed: Apr. 27, 1950. doi: 10.13870/j. cnki.stbcxb.2010.04.044.

YE, J. X. et al. Effect of combined application of organic manure and fertilizer on Chinese cabbage yield and quality. Journal of Jilin Agricultural University, v.26, n.2, p.155-157, 2004. Available from: <http://en.cnki.com.cn/Article_en/CJFDTOTALJLNY200402011.htm>. Accessed: Dec. 02, 2003. doi: 10.1007/ BF02873091.
ZHANG, X. P. et al. Effects of waxy maize relay intercropping and residue retention on rhizosphere microbial communities and vegetable yield in a continuous cropping system. Pedosphere, v.28, n.1, p.84-93, 2018. Available from: < http://d.wanfangdata. com.cn/periodical/trq-e201801007>. Accessed: May, 17, 2018. doi: 10.1016/S1002-0160(17)60332-1.

ZHAO, J. et al. Effects of organic-inorganic compound fertilizer with reduced chemical fertilizer application on crop yields, soil biological activity and bacterial community structure in a rice-wheat cropping system. Applied Soil Ecology, v.99, n.18, p.1-12, 2016. Available from: <https://doi.org/10.1016/j. apsoil.2015.11.006>. Accessed: Mar. 12, 2016. doi: 10.1016/j. apsoil.2015.11.006.

ZHAO, J. W.; ZHOU, L. R. Combined application of organic and inorganic fertilizers on black soil fertility and maize yield. Journal of Northeast Agricultural University, v.2, p.24-29, 2011. Available from: $\quad<$ https://doi.org/10.1016/S1006-8104(12)60005-1>. Accessed: Jun. 23, 2011. doi: CNKI:SUN:DBYN.0.2011-02-006.

ZHENG, W. et al. Changes in the soil bacterial community structure and enzyme activities after intercrop mulch with cover crop for eight years in an orchard. European Journal of Soil Biology, v.86, p.34-41, 2018. Available from: <https://doi.org/10.1016/j. ejsobi.2018.01.009>. Accessed: Mar. 22, 2018. doi: 10.1016/j. ejsobi.2018.01.009. 